\title{
Do Remittances Enhance Financial Development in Transitional Markets?
}

\author{
Kunofiwa Tsaurai \\ Ph.D., Associate Professor at the University of South Africa \\ Department of Finance, Risk Management and Banking, Pretoria, South Africa \\ e-mail: tsaurk@unisa.ac.za or kunofiwa.tsaurai@gmail.com
}

\section{Patience Hlupo}

Lecturer at Bindura University of Technology, Bindura, Zimbabwe

e-mail: phlupo@gmail.com

\section{Abstract}

The paper explored (1) the impact of remittances on financial development and (2) whether the interaction between remittances and human capital development had an influence on financial development in transitional economies using the dynamic GMM approach, with data ranging from 1996 to 2014. Remittances were found to have had a non-significant positive influence on financial development in transitional economies when stock market turnover, stock market value traded, domestic credit to the private sector by banks, and public bond sector development were used as measures of financial development. When stock market capitalisation, domestic credit to the private sector by financial sector, and private bond sector development were used as measures of financial development, remittances had a non-significance negative effect on financial development. Using all other measures of financial development except stock market capitalisation (which produced a negative sign), the interaction between remittances and human capital development had an insignificant positive influence on financial development. Transitional economies are therefore urged to avoid over-relying on remittance inflow and human capital development as sources of financial development.

Keywords: remittances; financial development; transitional economies

JEL: F24, G15, P2 


\section{Introduction}

Background of the study: Financial system efficiency has been lauded for its potential to positively impact savings, enhance investment activity and to result in improved economic performance in the long run (McKinnon 1973). Generally, the determinants of financial system performance are extensive, but it is imperative that a good understanding of these factors will help policymakers utilise these drivers to leverage financial development for the health of both their financial systems and the economy. The positive role of financial development on economic growth is undisputed and widely documented in the recent literature (Bongini et al. 2017). It is also important to note that remittances also have a positive direct influence on economic growth (Kumar et al. 2018). Thus, financial development and remittances are all important determinants of economic growth, but, it also is interesting to note that their interaction enhances Gross Domestic Product (GDP), according to Aggarwal et al. (2011). This is the basis upon which research on how to enhance financial system efficiency is justified.

Remittances have taken an upward trend according to World Bank reports. They sprang from $\$ 3$ billion in the mid-1970s to about $\$ 370$ billion by the beginning of the global financial crisis and further rose to US $\$ 441$ billion by 2016 (Ratha et al. 2016). Abundant literature concedes that remittances have emerged to be the second source of foreign finance to most developing countries, despite the fact that substantial migrant income remitted through informal channels is unaccounted for (Freund and Spatafora 2008) with Foreign Direct Investment (FDI) remaining in the lead position. It is confirmed that this growth has worked well to promote financial development (Aggarwal et al. 2006). Furthermore, remittances surpass capital flows in that they exhibit more stability and counter cyclicality, according to Yang (2008). The rising significance of remittances as an income source has necessitated investigations into channels through which remittances impact economic growth. According to key contributions to date, it is clear that remittances impact financial development, poverty, employment, human capital development, and foreign direct investment, among others. However, it is also critical to understand how the connections between remittances and human capital can foster efficient, deep, and stable financial systems.

Research problem and gaps found in the literature: Recent research work considers the linkage between remittances and human capital development (Azam and Raza 2016) while some concentrate on the effects of either remittance (Williams 2016; Bhattacharya et al. 2018) or human capital (Satrovic 2017) on financial development but ignore any possible interaction effects of remittances and human capital on financial development. In terms of the relationships that exist, mixed findings have been reported in the literature, with evidence of positive (Ajilore and Ikhide 2012), negative (Coulibaly 2015), and zero (Chowdhury 2016) associations between financial development and remittances. The same is true from a theoretical point of view, with Altruism Theory and Base Broadening Theory implying a positive relationship, while 
Self Interest Theory suggests a negative or insignificant link between the two. This diversity in findings and theoretical views leaves room for further investigation.

Turning to the measurement of financial development, it is important to note that most researchers measured financial development using one or only a few variables (Mbaye 2016). This does not bring out all the dimensions of financial development and gives misleading results biased towards the measure or few measures chosen. Also interesting to note is the fact that previous research mainly utilised bivariate data (Ajilore and Ikhide 2012); hence, it suffered greatly from omitted variable bias. Therefore, the authors came to the conclusion that there is a paucity of literature on remittances and financial sector development in transitional economies.

Contribution of the study: This study is important because the nexus between remittances and financial development is key to understanding the effect of the global financial crisis on transitional markets. A flashback to the recent trends shows that remittance issues dominate research and the policy agenda, according to the World Bank (2006). In addition, cross-country studies are very important in facilitating comparisons. The fundamental contribution of this study is that it investigates and explains the interaction effect of remittances and human capital on financial development, which is unexplored by previous research. In so doing, the study extends the literature on remittances and human capital development by clarifying how their interplay stimulates financial development.

This study deviates from the majority of prior similar studies in that it includes quite a number of variables in measuring financial development. The study used seven indicators of financial development. Hence, analysis of the effect of remittances on different measures of financial development help to provide an impartial view. The study also makes an important contribution to research on transitional economies by extending coverage to include more countries from diverse backgrounds. Transitional economies from Europe, Latin America, Asia, and Africa are included; hence, this work is pioneering in terms of coverage. Last but not least, our study captured a number of variables in order to avoid omitted variable bias, prevalent in other studies.

Organisation of the study: Section 2 of the paper is a theoretical and empirical literature review, while section 3 explains how the explanatory variables influence financial development. Section 4 discusses the personal remittances and financial development trends for transitional economies during the period from 1996 to 2014. Section 5 deals with the research methodology framework, the discussion, and the interpretation of the results. Section 6 concludes the paper. Section 7 is the bibliography.

\section{Literature review}

Empirical evidence on remittances and financial development is inconsistent, with some reporting no association, some positive, and some negative results, which are either unidirectional or bidirectional. Such disparities appear to emanate from incon- 
sistencies in the choice of study countries, measurement variables, econometric models, and the study period. However, every conclusion seems to be sensible, given there is always a theoretical underpinning to substantiate it. Some studies document evidence of there being no relationship between the two (Cherono 2013). A recent study by Coulibaly (2015) on 19 countries in Sub-Saharan Africa used liabilities to measure financial development and found no significant evidence of a relationship between the two. The converse relationship was also confirmed to be true, that financial development does not precede remittance flows.

The absence of a relationship between financial development and remittances is also evident in a study by Das (2009). The data for the study came from four economies which were receiving remittances from diasporans working in oil-producing companies in Arab countries. Financial development was proxied by investment. Combining the analysis of panel and time-series data, the study found no relationship between investment and remittances for Egypt, Syria, or Pakistan, but did for Bangladesh. Chowdhury (2016) reached a similar conclusion using a dynamic panel methodology to investigate how financial development can mediate the remittance-growth nexus for the 33 top beneficiary countries of remittances.

On the other hand, there is a fair share of research evidence showing the existence of a negative relationship between remittances and financial development. This supports the substitutability nature of remittances and financial development, where remittances provide an alternative access root to finance for individuals who cannot meet stringent requirements on loan applications. Mallick (2012) conducted a study in India to test the existence of a relationship between the two and confirmed that remittances have a crowding-out effect on household investment. Brown et al. (2013) combined macro and micro-economic analysis to study the linkage between financial literacy and remittances in Azerbaijan and Kyrgyzstan. The study found an adverse relationship between the two, suggesting that an increase in remitted funds constrains financial inclusion. This negative link was more pronounced for Azerbaijan, whose level of financial development was higher than that of Kyrgyzstan.

The other strand of researchers, for example, Gupta et al. (2009), argues for a positive relationship between financial development and remittances, meaning that they uphold the complementary hypothesis. A Mexican study by Demirgüç-Kunt et al. (2011) substantiates this strong positive remittance-development nexus by ascertaining a simultaneous increase in remittances, bank branches, account holders, and deposit base at the municipality level. Esteves and Khoudour-Castéras (2011) studied the effect of remitted inflows on the development of the financial system to peripheral European countries 40 years prior to the First World War. Their results show that the effect of remittances far exceeded that of other international capital flows, and the relationship was more robust than any studies using contemporary data. Ajilore and Ikhide (2012) examined the short and long-run dynamics of the interaction between remittances and financial sector development utilising data from Togo, Senegal, Nigeria, Lesotho, and Cape-Verde. They confirmed a long-run relationship from ARDL 
tests in all countries except Nigeria. In El Salvador, where the government actively engages migrant workers in bank remittances through state banks, Ambrosius (2011) determined that municipalities that were high on remittances were also high on savings per capita and accounts opened.

This complementary relationship between remittances and financial development has been proven to magnify the impact of remittances on economic growth in a number of empirical studies. Mundaca (2009) determined that developing financial systems is remittance enhancing in the long run in the Caribbean and Latin America, which in turn is a stimulus for economic growth. Bettin and Zazzaro (2012) developed a new measure for qualitative inefficiency of the local banking sector and demonstrated a positive effect of remitted income on the performance of the economy for efficient banks. This holds true even after controlling for institutional quality and different financial market determinants. The last group in the literature shows a reciprocated relationship between financial transfers and remittances. A study conducted on 39 countries in Latin America and the Caribbean by Fromentin (2015) found a strong, positive, two-way association between financial development and remittances. Irrefutably, empirical evidence on remittances and financial development is inconsistent, and it is inconceivable that a universal position can be devised. It is thus from this understanding that the current study seeks to investigate the same interrelationships in transitional economies.

\section{Explanatory variables}

Other factors that affect financial development are discussed in Table 1.

Table 1. Theory intuition and a priori expectation

\begin{tabular}{|l|l|l|c|}
\hline \multicolumn{1}{|c|}{ Variable } & \multicolumn{1}{|c|}{ Proxy used } & \multicolumn{1}{c|}{ Theory intuition } & $\begin{array}{c}\text { Expected } \\
\text { sign }\end{array}$ \\
\hline $\begin{array}{l}\text { Trade Open- } \\
\text { ness (OPEN) }\end{array}$ & $\begin{array}{l}\text { Exports } \\
\text { + Imports } \\
\text { (\% of GDP) }\end{array}$ & $\begin{array}{l}\text { The better the measure, the higher the possibility } \\
\text { of accessing better and more financial services in line } \\
\text { with the simultaneous openness hypothesis by Rajan } \\
\text { and Zingales (2003), which holds that a country should } \\
\text { be open both for trade and capital flows for its finan- } \\
\text { cial development. }\end{array}$ & + \\
\hline $\begin{array}{l}\text { Economic } \\
\text { growth } \\
\text { (GROWTH) }\end{array}$ & $\begin{array}{l}\text { GDP per } \\
\text { capita }\end{array}$ & $\begin{array}{l}\text { Robinson (1952) developed the demand-following } \\
\text { hypothesis, arguing that better economic performance } \\
\text { improves living standards, which induces a high } \\
\text { demand for financial services, leading to improved } \\
\text { banking sector activity. A study by Wahid et al. (2011) } \\
\text { established a stimulating effect of GDP on financial } \\
\text { development for Bangladesh. }\end{array}$ & + \\
\hline
\end{tabular}


Table 1. (continuous)

\begin{tabular}{|c|c|c|c|}
\hline Variable & Proxy used & Theory intuition & $\begin{array}{l}\text { Expected } \\
\text { sign }\end{array}$ \\
\hline Inflation & $\begin{array}{l}\text { Inflation } \\
\text { consumer } \\
\text { prices } \\
\text { (annual \%) }\end{array}$ & $\begin{array}{l}\text { A theory underpinning the negative inflation-finance } \\
\text { nexus by Huybens and Smith (1999) explains that } \\
\text { inflation induces credit rationing by banks, leading } \\
\text { to reduced activity in financial markets. Conceding, } \\
\text { Bittencourt (2008) observed that an increase } \\
\text { in inflation negatively affected financial market } \\
\text { performance in Brazil. In contrast, Sogut (2008) found } \\
\text { a positive link between inflation and banking sector } \\
\text { development for low-income economies. }\end{array}$ & $+/-$ \\
\hline $\begin{array}{l}\text { Foreign } \\
\text { Direct } \\
\text { Investment }\end{array}$ & $\begin{array}{l}\text { Net FDI } \\
\text { (as a ratio } \\
\text { to GDP) }\end{array}$ & $\begin{array}{l}\text { Misun and Tomsik (2002) found that foreign direct } \\
\text { investment crowds out private investment in Poland. } \\
\text { Contrary to the above two positions, Agosin and } \\
\text { Machado (2005) concluded there is independence } \\
\text { between foreign capital flows and private domestic } \\
\text { investment in Africa after observing an insignificant } \\
\text { association between the two. }\end{array}$ & $+/-$ \\
\hline Remittances & $\begin{array}{l}\text { Personal } \\
\text { remittances } \\
\text { received } \\
\text { (\% of GDP) }\end{array}$ & $\begin{array}{l}\text { Lucas and Stark (1985) opined that migrants invest } \\
\text { remittances in order to accumulate returns for } \\
\text { a better status when they return home. Opposing } \\
\text { theoretical reasoning from the popular finances view } \\
\text { says remittances substitute credit. However, Karikari } \\
\text { et al. (2016) found evidence of a negative relationship } \\
\text { between remittances and financial development } \\
\text { in Africa. }\end{array}$ & $+/-$ \\
\hline Savings & $\begin{array}{l}\text { Gross } \\
\text { domestic } \\
\text { savings } \\
\text { (\% of GDP) }\end{array}$ & $\begin{array}{l}\text { Dorrucci et al. (2009) disapproved of the use of savings } \\
\text { to augment financial development in emerging } \\
\text { markets. Mbulawa (2015) determined that savings } \\
\text { sapped financial development for Southern African } \\
\text { Development Countries since it is a leakage from the } \\
\text { usual flow of funds. }\end{array}$ & - \\
\hline $\begin{array}{l}\text { Human Cap- } \\
\text { ital Devel- } \\
\text { opment }\end{array}$ & $\begin{array}{l}\text { Human capital } \\
\text { development } \\
\text { index }\end{array}$ & $\begin{array}{l}\text { Human capital theory (Becker, 1964) postulates that } \\
\text { knowledge, creativity, and skills empower individuals } \\
\text { to take appropriate financial decisions. Meisenberg and } \\
\text { Lynn's (2011) comparative study on Japan and Nigeria } \\
\text { contends that human capital positively influences } \\
\text { economic consequences. }\end{array}$ & + \\
\hline $\begin{array}{l}\text { The } \\
\text { interaction } \\
\text { between } \\
\text { remittances } \\
\text { and human } \\
\text { capital de- } \\
\text { velopment }\end{array}$ & $\begin{array}{l}\text { Interaction } \\
\text { term } \\
\text { (remittances } \\
\times \text { HCD) }\end{array}$ & $\begin{array}{l}\text { A priori, the interaction between remittances and } \\
\text { human capital development undermines financial } \\
\text { development, as individuals substitute remittances } \\
\text { for credit to finance education and health expenses, } \\
\text { (Stahl 1982). Stahl further argued that migration } \\
\text { is a withdrawal of human capital, which affects the } \\
\text { stability of financial systems due to brain drain. } \\
\text { By contrast, Rapoport and Docquier's (2005) } \\
\text { theoretical argument is that remittances may } \\
\text { be a source of funds for the repayment of loans taken } \\
\text { to finance the education of migrants, in which case } \\
\text { it may complement financial development. }\end{array}$ & $+/-$ \\
\hline
\end{tabular}

Source: author's own compilation. 
Do Remittances Enhance Financial Development in Transitional Markets?

\section{Trend analysis}

Table 2 shows the mean values of each variable for every country during the period from 1996 to 2014.

Table 2. Mean personal remittances received and financial development trends in transitional economies (1996-2014)

\begin{tabular}{|c|c|c|c|c|c|c|c|c|}
\hline & REMIT & DCFIN & TURN & VTRADED & MCAP & DCRED & ODPR & ODPUB \\
\hline \multicolumn{9}{|c|}{ Europe } \\
\hline Greece & 0.96 & 107.76 & 55.80 & 26.88 & 48.38 & 79.38 & 12.72 & 59.03 \\
\hline Poland & 1.35 & 48.01 & 40.15 & 9.57 & 25.27 & 33.42 & 1.04 & 20.70 \\
\hline Portugal & 0.65 & 149.94 & 62.49 & 23.93 & 37.07 & 143.62 & 39.24 & 37.51 \\
\hline Russia & 0.28 & 32.24 & 41.42 & 24.55 & 44.38 & 30.07 & 3.29 & 4.77 \\
\hline Turkey & 0.78 & 52.92 & 145.74 & 38.98 & 28.41 & 32.49 & 0.36 & 25.82 \\
\hline \multicolumn{9}{|c|}{ Latin America } \\
\hline Argentina & 0.13 & 32.43 & 17.98 & 3.04 & 15.49 & 15.03 & 4.65 & 13.99 \\
\hline Brazil & 0.23 & 80.72 & 55.18 & 25.15 & 45.84 & 41.79 & 17.96 & 48.40 \\
\hline Colombia & 1.72 & 50.98 & 11.00 & 4.74 & 33.81 & 35.76 & 0.45 & 19.48 \\
\hline Mexico & 1.88 & 36.92 & 28.27 & 8.11 & 29.34 & 20.53 & 11.94 & 16.19 \\
\hline Peru & 1.55 & 20.79 & 11.62 & 3.47 & 36.26 & 25.02 & 10.73 & 3.27 \\
\hline \multicolumn{9}{|c|}{ Asia } \\
\hline China & 0.19 & 132.53 & 159.46 & 65.90 & 42.85 & 116.12 & 18.16 & 11.91 \\
\hline Hong Kong & 0.12 & 159.72 & 55.58 & 370.51 & 673.17 & 164.85 & 16.17 & 17.33 \\
\hline Indonesia & 0.93 & 47.51 & 38.94 & 11.45 & 32.55 & 31.32 & 3.84 & 12.84 \\
\hline India & 3.11 & 60.56 & 111.04 & 46.46 & 58.26 & 38.29 & 2.04 & 9.65 \\
\hline Malaysia & 0.48 & 134.41 & 30.25 & 41.60 & 145.61 & 121.83 & 47.61 & 35.38 \\
\hline Philippines & 10.35 & 55.07 & 22.21 & 12.05 & 54.57 & 35.61 & 0.71 & 30.26 \\
\hline South Korea & 0.69 & 121.93 & 184.82 & 106.51 & 63.44 & 110.74 & 56.79 & 23.58 \\
\hline Thailand & 1.11 & 137.82 & 74.41 & 43.78 & 58.93 & 118.64 & 24.56 & 18.24 \\
\hline \multicolumn{9}{|c|}{ Africa } \\
\hline South Africa & 0.23 & 167.64 & 25.87 & 51.64 & 198.75 & 135.58 & 15.71 & 33.52 \\
\hline Overall mean & 1.41 & 85.78 & 61.70 & 48.33 & 88.02 & 70.00 & 15.16 & 23.26 \\
\hline
\end{tabular}

Source: author's own compilation.

Only five countries (Colombia, Mexico, Peru, India, and the Philippines) had their mean personal remittances received as a ratio of GDP above the overall mean personal remittances ratio of $1.41 \%$ of GDP. India and the Philippines are outliers because their individual mean personal remittances ratio is far higher than the overall mean personal remittances ratio. Greece, Portugal, China, Hong Kong, Malaysia, South Korea, Thailand, and South Africa had their individual mean domestic credit provided by the financial sector ratios much higher than the overall mean domestic credit provided by the financial sector ratio.

On stock market turnover, Turkey, China, India, and South Korea are outliers because their individual stock market turnover ratios far exceed the overall mean stock 
market turnover ratio of $61.70 \%$. On the other hand, Colombia, Mexico, Peru, the Philippines, and South Africa are also outliers because their individual mean stock market turnover ratios are far below the overall mean value. There are only four countries whose mean stock market value traded ratios are above the overall mean stock market value traded ratio of $48.33 \%$ of GDP, namely China, Hong Kong, South Korea, and South Africa. Hong Kong, South Korea, Poland, Argentina, Colombia, Mexico, Peru, Indonesia, and the Philippines are outliers because their mean stock market value traded deviated by a wider margin from the overall mean value.

Only three countries (Hong Kong, Malaysia, and South Africa) had their individual mean stock market capitalisation ratio above the overall mean stock market capitalisation ratio of $88.02 \%$ of GDP. These countries are also outliers. The ratio of domestic private credit by banks to GDP for Greece, Portugal, China, Hong Kong, Malaysia, South Korea, Thailand, and South Africa was above the overall mean domestic private credit by banks ratio of $70 \%$ of GDP. With the exception of Greece, all other countries whose individual mean domestic private credit by banks ratio exceeded the mean ratio are outliers. Argentina, Mexico, and Peru are also outliers because their individual mean domestic private credit by banks ratios are far lower than the overall mean domestic private credit by banks ratio of 70\% of GDP.

On private bond sector development, countries such as South Korea, the Philippines, Poland, Portugal, Russia, Turkey, Argentina, Colombia, Indonesia, India, and Malaysia are outliers. This is because the deviation between their individual and overall mean private bond sector development ratio is too wide. Countries whose mean public bond sector development ratios exceeded the overall mean public bond sector development of 23.26\% of GDP are Greece, Portugal, Turkey, Brazil, Malaysia, the Philippines, South Korea, and South Africa. Outlier countries include Greece, Portugal, Russia, Argentina, Brazil, Peru, China, Indonesia, India, Malaysia, and South Africa because their individual mean public bond sector development ratios deviated too much from the overall mean public bond sector development ratio of $23.26 \%$ of GDP.

\section{Research methodology}

Data, description and sources: The paper used 19 years of secondary panel data, ranging from 1996 to 2014. The data were mainly collected from the World Bank, the International Monetary Fund (IMF), and the Global Financial Indicators databases. Alongside data availability constraints, the International Monetary Fund's (2015) list of transitional economies was used to select the countries to be included in the current study. These countries included Argentina, Indonesia, China, Colombia, Brazil, Greece, Hong Kong, India, South Africa, Malaysia, the Philippines, Mexico, Peru, South Korea, Russia, Thailand, Poland, Portugal, and Turkey.

Econometric models for the current study: The general model specification for the current study is represented by equation 1 . 


$$
F I N=f(R E M I T, H C D, F D I, O P E N, S A V, \text { GROWTH, INFL })
$$

In econometric terms, equation 1 is transformed into equation 2 below.

$$
\begin{gathered}
F I N_{i, t}=\beta_{0}+\beta_{1} \text { IIN }_{i, t-1}+\beta_{2} \text { REMIT }_{i, t}+\beta_{3} H C D_{i, t}+\beta_{4} F D I_{i, t}+ \\
\beta_{5} \text { OPEN }_{i, t}+\beta_{6} S A V_{i, t}+\beta_{7} \text { GROWTH }_{i, t}+\beta_{8} I N F L_{i, t}+\varepsilon_{i t}
\end{gathered}
$$

where $\beta_{0}$ is the intercept term, $\beta_{1}$ to $\beta_{9}$ are coefficients of the variables, and $\varepsilon_{i t}$ is the error term. $t$ stands for time while $i$ represents the country.

In order to investigate whether personal remittance and human capital development complemented or substituted each other in enhancing financial development, and also taking into account the dynamic nature of the financial development data, equation 2 is transformed into equation 3, consistent with Nor et al. (2015).

$$
\begin{gathered}
F I N_{i, t}=\beta_{0}+\beta_{1} \text { FIN }_{i, t-1}+\beta_{2} \text { REMIT }_{i, t}+\beta_{3} H C D_{i, t}+ \\
\beta_{4}\left(\text { REMIT }_{i, t} \cdot H C D_{i, t}\right)+\beta_{5} F D I_{i, t}+\beta_{6} \text { OPEN }_{i, t}+ \\
\beta_{7} \text { SAV V }_{i, t}+\beta_{8} \text { GROWTH }_{i, t}+\beta_{9} I N F L_{i, t}+\varepsilon_{i t}
\end{gathered}
$$

FINit-1is the lag of financial development in support of a theoretical view by Almalki and Batayneh (2015). Following Tsaurai (2018), the interaction term $\operatorname{REMIT}_{i, t}$. $H C D_{i, t}$ is introduced in order to be able to investigate whether human capital development and personal remittances substituted or complemented each other in developing the financial sector in emerging markets.

Discussion and interpretation of results: In line with Chindo and Rahim (2017) and Tsaurai (2018), among others, the current study used four panel unit root tests, including the Fisher-PP test (Choi 2003), Levin et al. (2002), the Fisher-ADF test (Madala and $\mathrm{Wu}$ 1999) and Im et al. (2003) - see the results in Table 3.

Where SCAP, STURN, SVALUE, DCFIN, DCBANKS, PVBOND and PBBOND respectively stand for stock market capitalization, stock market turnover, stock market value traded, domestic credit by the financial sector, domestic private credit by banks, private bond sector development proxied by outstanding domestic private debt securities (\% of GDP), and public bond sector development as measured by outstanding domestic public debt securities (\% of GDP).

The study assumed the existence of a null hypothesis which says that there is a unit root in the panel. At level, the study could not reject the null hypothesis for all the variables at $1 \%$ significance level. However, at first difference, the study rejected the null hypothesis at the $1 \%$ level of significance for all the variables. In other words, the data for all the variables studied were found to be stationary at first difference. 
ด ঐ)

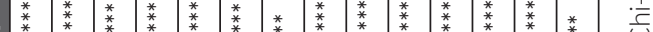
荈

志

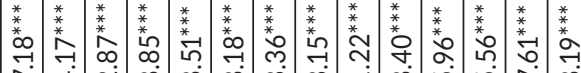

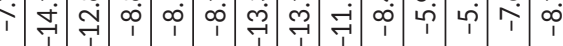

J

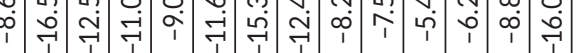

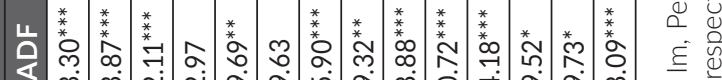

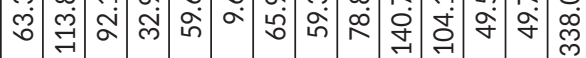

ล లె

ल

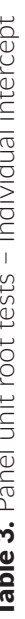

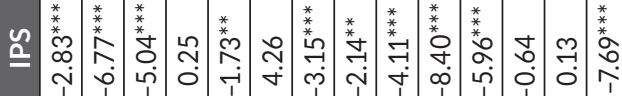

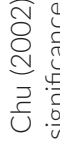

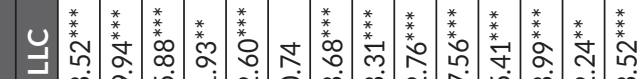
这哭

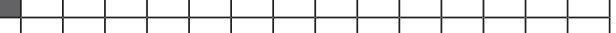


The Kao (1999) approach for panel co-integration was used in this study. The panel co-integration method's null hypothesis says that there is no co-integration among the variables studied.

Table 4. Results of Kao co-integration tests

\begin{tabular}{|l|l|}
\multicolumn{1}{|c|}{ Series } & ADF t-statistic \\
\hline SCAP REMIT HCD FDI OPEN SAV GROWTH INFL & $-2.8666^{* * *}$ \\
\hline STURN REMIT HCD FDI OPEN SAV GROWTH INFL & $-3.0781^{* * *}$ \\
\hline SVALUE REMIT HCD FDI OPEN SAV GROWTH INFL & $-3.1998^{* * *}$ \\
\hline DCFIN REMIT HCD FDI OPEN SAV GROWTH INFL & $-4.6800^{* * *}$ \\
\hline DCBANKS REMIT HCD FDI OPEN SAV GROWTH INFL & $-6.3896^{* * *}$ \\
\hline PVBOND REMIT HCD FDI OPEN SAV GROWTH INFL & $-1.3737^{*}$ \\
\hline PBBOND REMIT HCD FDI OPEN SAV GROWTH INFL & $-8.3534^{* * *}$ \\
\hline
\end{tabular}

Source: author's own compilation.

From the results presented in Table 4, the study rejected the null hypothesis for all the series. In other words, there is a long-run relationship between and or among the variables studied.

Table 5 shows the results of the dynamic GMM estimation technique.

Table 5. Dynamic GMM (Arellano and Bond, 1991) Results

\begin{tabular}{|l|l|l|c|c|c|c|c|}
\cline { 2 - 8 } \multicolumn{1}{c|}{} & Model 1 & Model 2 & Model 3 & Model 4 & Model 5 & Model 6 & Model 7 \\
\hline FIN & $0.79^{* * *}-1$ & $0.88^{* * *}$ & $0.90^{* * *}$ & $0.98^{* * *}$ & $0.97^{* * *}$ & $0.95^{* * *}$ & $0.90^{* * *}$ \\
\hline REMIT & -0.03 & 0.02 & 0.02 & -0.001 & 0.02 & -0.02 & 0.04 \\
\hline HCD & -0.03 & -0.36 & 0.31 & -0.06 & $-0.15^{*}$ & 0.24 & 0.09 \\
\hline REMIT.HCD & -0.05 & 0.09 & 0.16 & 0.01 & 0.05 & 0.04 & 0.16 \\
\hline FDI & 0.002 & -0.02 & -0.02 & -0.002 & -0.002 & 0.01 & -0.002 \\
\hline OPEN & $0.17^{* * *}$ & 0.02 & 0.09 & -0.006 & -0.006 & 0.03 & $0.08^{* *}$ \\
\hline SAV & 0.06 & $0.15^{*}$ & $0.15^{*}$ & -0.003 & 0.03 & 0.01 & $-0.11^{* *}$ \\
\hline GROWTH & -0.01 & 0.05 & -0.02 & $0.02^{* *}$ & $0.05^{* * *}$ & -0.01 & -0.01 \\
\hline INFL & -0.03 & 0.01 & -0.01 & -0.002 & -0.01 & $-0.08^{* * *}$ & 0.01 \\
\hline $\begin{array}{l}\text { Adjusted } \\
\text { R-squared }\end{array}$ & 0.80 & 0.80 & 0.87 & 0.98 & 0.98 & 0.94 & 0.91 \\
\hline J-statistic & 351 & 351 & 351 & 351 & 351 & 351 & 351 \\
\hline $\begin{array}{l}\text { Prob } \\
\text { (J-statistic) }\end{array}$ & 0.00 & 0.00 & 0.00 & 0.00 & 0.00 & 0.00 & 0.00 \\
\hline
\end{tabular}

***, ${ }^{* *}$ and ${ }^{*}$ denote $1 \%, 5 \%$ and $10 \%$ levels of significance, respectively

Source: author's own compilation from E-Views.

Across all the seven models, financial development was found to have been positively and significantly affected by its lag, consistent with Almalki and Batayneh (2015). In model 1, personal remittances had a negative but non-significant impact on stock market capitalisation. The direction of influence is consistent with Kimani 
and Mutuku (2003). In contrast to the theoretical expectations and findings by Meisenberg and Lynn (2011), human capital development also had a non-significant negative effect on stock market capitalisation. Stock market capitalisation in emerging markets studied was found to have been negatively but non-significantly affected by the interaction between personal remittances and human capital development. In other words, evidence showing that personal remittances and human capital development complemented each other to enhance stock market capitalisation was not detected in model 1.

In model 2, personal remittances had a positive but non-significant effect on stock market turnover while human capital development's influence on stock market turnover was negative but insignificant. However, the interaction between personal remittances and human capital development was found to have had a positive but non-significant effect on stock market turnover. Although human capital development was found to have had a negative effect on stock market turnover, the interaction between personal remittances and human capital development improved stock market turnover in model 2, which is a new contribution to the empirical evidence, as previous studies do not include interaction effects. This resonates with the human capital theory by Becker (1964), who argued that human capital investment facilitates skills and knowledge acquisition, which in this case gives more confidence to trade more on stock markets, hence the high turnover.

Although personal remittances and human capital development had a separate non-significant positive influence on stock market value traded in model 3, the interaction between the two variables had an insignificant positive effect on stock market value traded in the same model. It is clear in model 3 that human capital development enhanced the positive impact of personal remittances on stock market value traded. The finding is consistent with the Complementarity Hypothesis and remittance growth literature. Despite the fact that both personal remittances and human capital development had a non-significant negative influence on domestic credit by the financial sector, the combination of the two variables had an insignificant positive effect on domestic credit by the financial sector in model 4 . The finding provides evidence that the complementarity between personal remittances and human capital development had an enhancing influence on domestic credit by the financial sector, in line with theoretical postulations (Rapoport and Docquier 2005). In model 5, personal remittances had a non-significant positive effect on domestic private credit by banks, while human capital development's influence on domestic private credit by banks was significantly negative. However, the interaction between personal remittances and human capital development had an insignificant positive impact on domestic private credit by banks, consistent with the altruistic hypothesis where migrants finance their families' education through remittances while crowding out domestic credit. Hence, the family members are less likely to seek domestic credit, but should they want to borrow, they stand a better chance of accessing local credit if remittances come through formal channels. This explains the insignificant effect on domestic credit. 
In model 6, personal remittances' effect on outstanding domestic private debt securities was negative but insignificant, while human capital development had a positive but non-significant effect on outstanding domestic private debt securities in the same model. Just like in models $2,3,4$, and 5 , the combination of personal remittances and human capital development had a non-significant positive influence on financial development as proxied by outstanding domestic private debt securities. Both personal remittances and human capital development separately had an insignificant positive influence on outstanding domestic public debt securities in model 7. On the other hand, the combination of personal remittances and human capital development's influence on outstanding domestic public debt securities was positive but non-significant in model 7. The finding resonates with the Popular Finances view where remitted funds are saved through local cooperatives and savings clubs, rather than finding their way to the formal channels as public debt. This provides easy access to the funds should the saver require an educational loan later. Hence, the effect on public bonds is negligible.

\section{Conclusion}

The paper explored (1) the impact of remittances on financial development and (2) whether the interaction between remittances and human capital development had an influence on financial development in transitional economies using the dynamic GMM approach, with data ranging from 1996 to 2014. Remittances were found to have had a non-significant, positive influence on financial development in transitional economies when stock market turnover, stock market value traded, domestic credit to the private sector by banks, and public bond sector development were used as measures of financial development. When stock market capitalisation, domestic credit to the private sector by the financial sector, and private bond sector development were used as measures of financial development, remittances had a non-significant negative effect on financial development. Using all other measures of financial development except stock market capitalisation (which produced a negative sign), the interaction between remittances and human capital development had an insignificant, positive influence on financial development. Transitional economies are, therefore, urged to avoid over-relying on remittance inflow and human capital development as sources of financial development. The study has two limitations, namely (1) more transitional economies would have been included in the sample if the data were available, and (2) other measures of financial development would have been part of the model if the data could have been found. 


\section{References}

Abida, Z. and Sghaier, I.M. (2014), Remittances, Financial Development and Economic Growth: The Case of North African Countries, "Romanian Economic Journal", 17 (51), pp. 137-170.

Aggarwal, R., Demirguc-Kunt, A. and Martinez Peria, M.S. (2006), Do workers' remittances promote financial development? World Bank, (2014). "Annual Remittance Data”, in World Bank (ed.), Remittance Data, Washington D.C.

Aggarwal, R., Demirgüç-Kunt, A. and Peria, M.S.M. (2011), Do remittances promote financial development?, "Journal of Development Economics", 96 (2), pp. 255-264.

Agosin, M.R. and Machado, R. (2005), Foreign Investment in Developing Countries: Does it Crowd in Domestic Investment?, "Oxford Development Studies", 33 (2), pp. 149-162.

Ajilore, T. and Ikhide, S. (2012), A bounds testing analysis of migrant remittances and financial development in selected Sub-Sahara African countries, "Review of Finance \& Banking”, 4 (2), pp. 79-96.

Almalki, A. and Batayneh, K. (2015), The relationship between inflation and financial development in Saudi Arabia, Proceedings of the Australasian Conference on Business and Social Science 2015, Sydney (in partnership with The Journal of Developing Areas), pp. 421-427.

Ambrosius, C. (2011), Remittances and financial sector development. Lessons from the Salvadoran case, "Savings and Development", 35 (1), pp. 1-27.

Arcand, J.L., Berkes, E. and Panizza, U. (2015), Too Much Finance?, "Journal of Economic Growth", 20 (2), pp. 105-48.

Arellano, M. and Bond, S. (1991), Some tests of specification for panel data: Monte Carlo evidence and an application to employment equations, "The Review of Economic Studies", 58 (2), pp. 277-297.

Azam, M. and Raza, S.A. (2016), Do workers' remittances boost human capital development, "Pakistan Development Review", 55 (2), pp. 123-150.

Becker, G.S. (1964), Human capital: A theoretical and empirical analysis with special reference to education, University of Chicago Press, Chicago.

Bettin, G. and Zazzaro, A. (2012), Remittances and financial development: substitutes or complements in economic growth?, "Bulletin of Economic Research", 64 (4), pp. 509-536.

Bhattacharya, M., Inekwe, J. and Paramati, S.R. (2018), Remittances and financial development: empirical evidence from heterogeneous panel of countries, "Applied Economics", 50 (38), pp. 4099-4112.

Bittencourt, M. (2008), Inflation and Financial Development: Evidence from Brazil, Working Papers 67, Economic Research Southern Africa.

Bongini, P., Iwanicz-Drozdowska, M., Smaga, P. and Witkowski, B. (2017), Financial Development and Economic Growth: The Role of Foreign-Owned Banks in CESEE Countries, "Sustainability", 9 (3), p. 335.

Brown, R.P., Carmignani, F. and Fayad, G. (2013), Migrants' remittances and financial development: Macro-and micro-level evidence of a perverse relationship, "The World Economy", 36 (5), pp. 636-660. 
Cherono, M.R. (2013), The effect of remittances and financial development on private investment in Kenya.

Chindo, S. and Rahim, A.S. (2017), Air pollution and life expectancy in G7 countries: An application of panel dynamic ordinary least squares (DOLS) approach, Kuala Lumpur International Communication, Education, Language and Social Science Conference.

Choi, I. (2003), Unit root tests for panel data, "Journal of International Money and Finance", 20 (2), pp. 249-272.

Chowdhury, M. (2016), Financial development, remittances and economic growth: Evidence using a dynamic panel estimation, "The Journal of Applied Economic Research", 10 (1), pp. 35-54.

Cojocaru, L., Falaris, E.M., Hoffman, S.D. and Miller, J.B. (2016), Financial system development and economic growth in transition economies: New empirical evidence from the CEE and CIS countries, "Emerging Markets Finance and Trade", 52 (1), pp. 223-236.

Coulibaly, D. (2015), Remittances and financial development in Sub-Saharan African countries: A system approach, "Economic Modelling”, 45, pp. 249-258.

Das, A. (2009), The Effect of Transfers on Investment and Economic Growth: Do Remittances and Grants Behave Similarly? Memo, University of Manitoba.

Demetriades, P.O. and Rousseau P.L. (2015), The Changing Face of Financial Development, Department of Economics Working Paper No. 15/20, University of Leicester.

Demirgüç-Kunt, A., Córdova, E.L., Peria, M.S.M. and Woodruff, C. (2011), Remittances and banking sector breadth and depth: Evidence from Mexico, "Journal of Development Economics", 95 (2), pp. 229-241.

Dorrucci, E. Meyer-Cirkel, A. and Santabarbara, D. (2009), Domestic development in emerging economies: evidence and implications, European Central bank, Occasional paper series, No. 102.

Esteves, R. and Khoudour-Castéras, D. (2011), Remittances, capital flows and financial development during the mass migration period, 1870-1913, "European Review of Economic History", 15 (3), pp. 443-474.

Freund, C. and Spatafora, N. (2008), Remittances, transaction costs, and informality, "Journal of Development Economics", 86 (2), pp. 356-366.

Fromentin, V. (2015), Migrant's remittances and Financial Development in Latin America and the Caribbean countries: A dynamic approach, Cahier de Recherche, pp. 2-27.

Giuliano, P. and Ruiz-Arranz, M. (2009), Remittances, financial development, and growth, "Journal of Development Economics", 90 (1), pp. 144-152.

Gupta, S., Pattillo, C.A and Wagh, S. (2009), Effect of Remittances on Poverty and Financial Development in Sub-Saharan Africa, "World Development", 37 (1), pp. 104-115.

Huybens, E. and Smith, B. (1999), Inflation, financial markets and long-run real activity. "Journal of Monetary Economics", 43 (2), pp. 283-315.

Im, K. S., Pesaran, M.H. and Shin, Y. (2003), Testing unit roots in heterogeneous panels, "Journal of Econometrics", 115 (1), pp. 53-74.

International Monetary Fund (2015). World Economic Outlook: Adjusting to Lower Commodity Prices. Washington (October).

Kao, C. (1999), Spurious regression and residual-based tests for co-integration in panel data, "Journal of Econometrics", 90, pp. 1-44. 
Karikari, N.K., Mensah, S. and Harvey, S.K. (2016), Do remittances promote financial development in Africa?, "SpringerPlus", 5 (1), pp. 1-21.

Kimani, K. and Mutuku, M. (2013), Inflation Dynamics on the Overall Stock Market Performance: The Case of Nairobi Securities Exchange in Kenya, "Economics and Finance Review Journal", 2 (11), pp. 1-11.

Kumar, R.R., Stauvermann, P.J., Patel, A. and Prasad, S. (2018), The effect of remittances on economic growth in Kyrgyzstan and Macedonia: accounting for financial development, "International Migration", 56 (1), pp. 95-126.

Levin, A., Lin, C.F. and Chu, C.S.J. (2002), Unit root tests in panel data: Asymptotic and finite-sample properties, "Journal of Econometrics", 108 (1), pp. 1-24.

Lucas, R.E.B. and Stark, O. (1985), Motivations to remit: Evidence from Botswana, "Journal of Political Economy", 93, pp. 901-918.

Madala, G.S. and Wu, S. (1999), A comparative study of unit root tests with panel data and a new simple test, "Oxford Bulletin of Economics and Statistics", Special Issue, pp. 631-652.

Mallick, H. (2012), Inflow of remittances and private investment in India, "The Singapore Economic Review", 57 (01), 1250004.

Mbaye, L. (2016), Working Paper 232-Remittances and Access to rural credit markets Evidence from Senegal, African Development Bank.

Mbulawa, S. (2015), Determinants of economic growth in Southern Africa development community: The role of institutions, "Applied Economics and Finance", 2 (2), pp. 91-102.

McKinnon R.I. (1973), Money and capital in economic development, Brookings Institute, Washington, D. C.

Meisenberg, G. and Lynn, R. (2011), Intelligence: A measure of human capital in nations, "The Journal of Social, Political and Economic Studies", 36 (4), pp. 421-454.

Misun, J. and Tomsik, V. (2002), Does Foreign Direct Investment Crowd in or Crowd Out Domestic Investment, "Eastern European Economics", 40 (2), 38-56.

Mundaca, B.G. (2009), Remittances, financial market development, and economic growth: the case of Latin America and the Caribbean, "Review of Development Economics", 13 (2), pp. 288-303.

Nor, N.H.H.M, Ripain, N. and Ahmad, N.W. (2015), Financial development and FDI-Growth nexus: Panel Analysis, Proceeding of the $2^{\text {nd }}$ International Conference on Management and Muamalah, pp. 435-446.

Rajan, R.G. and Zingales, L. (2003), The great reversals: The politics of financial development in the twentieth century, "Journal of Financial Economics", 69 (2), pp. 5-50.

Rapoport, H. and Docquier, F. (2005), The Economics of Migrants' Remittances, IZA discussion papers, Institute for the Study of Labor (IZA).

Ratha, D., Eigen-Zucchi, C. and Plaza, S. (2016), Migration and remittances Factbook 2016, ed. World Bank Group (World Bank Publications).

Robinson, J. (1952), The generalization of the general theory, in the rate of interest and other essays. London: Macmillan.

Romer, P. (1986), Increasing returns and long run economic growth, "Journal of Political Economy”, 94 (5), pp. 1002-1037.

Satrovic, E. (2017), Financial Development and Human Capital in Turkey: ARDL Approach, "Cappadocia Academic Review", 1 (2), pp. 1-15. 
Shahzad, S.J.H., Adnan, N., Sajid, A.L.I. and Naveed, R.A.Z.A. (2014), Impact of Remittances On Financial Development In South Asia, "Review of Economic and Business Studies", 7 (2), pp. 11-29.

Sogut, E. (2008), The determinants of Financial development and private sector credits: Evidence from panel data, Middle East Technical University, Masters thesis.

Stahl, C.W. (1982), Labour emigration and economic development, "International Migration Review", 16 (4), pp. 869-899.

Tsaurai, K. (2018), FDI-led financial development hypothesis in emerging markets: the role of human capital development, "International Journal of Education Economics and Development”, 9 (2), pp. 109-123.

Wahid, M.N.A., Shahbaz, M. and Azim, P. (2011), Inflation and financial sector correlation: The case of Bangladesh, "International Journal of Economics and Financial Issues", 14 (2), pp. 145-152.

Williams, K. (2016), Remittances and Financial Development: Evidence from Sub-Saharan Africa, "African Development Review", 28 (3), pp. 357-367.

World Bank (2006), Global Economic Prospects: Economic Implications of Remittances. Yang, D. (2008), International Migration, remittances and household investment: Evidence from Philippine Migrants' Exchange Rate Shocks, "Economic Journal", 118 (528), pp. 591-630.

\section{Streszczenie}

\section{Czy przekazy pieniężne wzmacniają rozwój finansowy na rynkach przejściowych?}

W artykule przeanalizowano (1) wpływ przekazów pieniężnych na rozwój finansowy oraz (2) zbadano czy interakcja między przekazami pieniężnymi a rozwojem kapitału ludzkiego miała wpływ na rozwój finansowy w gospodarkach przejściowych. Wykorzystano dynamiczne podejście GMM w oparciu o dane z okresu 1996-2014. Przyjęcie jako miar rozwoju finansowego wartości obrotów giełdowych, wolumenu obrotów na rynku akcji, kredytów krajowych dla sektora prywatnego udzielanych przez banki oraz rozwoju sektora obligacji publicznych, pozwoliło na wykazanie, że przekazy pieniężne miały nieistotny pozytywny wpływ na rozwój finansowy w gospodarkach przejściowych. Kiedy jako mierniki rozwoju finansowego przyjęto kapitalizację rynku akcji, kredyty krajowe dla sektora prywatnego udzielane przez sektor finansowy oraz rozwój sektora obligacji prywatnych, przekazy pieniężne nie miały istotnego negatywnego wpływu na rozwój finansowy. Zastosowanie wszystkich innych miar rozwoju finansowego, z wyjątkiem kapitalizacji rynku akcji (która dawała znak ujemny) pozwoliło na wykazanie, że interakcja między przekazami pieniężnymi a rozwojem kapitału ludzkiego miała nieznaczny pozytywny wpływ na rozwój finansowy. Wzywa się zatem gospodarki przejściowe, aby unikały nadmiernego polegania na wpływach z przekazów pieniężnych i na rozwoju kapitału ludzkiego jako źródłach rozwoju finansowego.

Słowa kluczowe: przekazy pieniężne, rozwój finansowy, gospodarki przejściowe 